\title{
Assessing debris flow activity in a changing climate
}

\author{
Thea Turkington ${ }^{1}$ - Alexandre Remaître ${ }^{2} \cdot$ Janneke Ettema $^{1}$ • \\ Haydar Hussin ${ }^{1}$ - Cees van Westen ${ }^{1}$
}

Received: 4 June 2015 / Accepted: 19 March 2016 / Published online: 4 April 2016

(C) The Author(s) 2016. This article is published with open access at Springerlink.com

\begin{abstract}
Future trends in debris flow activity are constructed based on bias-corrected climate change projections using two meteorological proxies: daily precipitation and Convective Available Potential Energy (CAPE) combined with specific humidity for two Alpine areas. Along with a comparison between proxies, future number of days with debris flows are analyzed with respect to different regional and global climate models, Representative Concentration Pathways (RCPs), and area for quantile mapping. Two different base periods are also analyzed, as debris flows were observed on only 6 (17) days between 1950 and 1979, yet on 18 (49) days between 1980 and 2009 for Fella River, NE Italy (Barcelonnette, SE French Alps). For both areas, future climate projections vary between no change up to an increase of $6.0 \%$ per decade in days with debris flow occurrences towards the end of $21 \mathrm{st}$ century. In Barcelonnette, the base period and proxy have a bigger impact on the future number of debris flow days than the climate model or RCP used. In Fella River, the base period, RCP, and proxy used define the future range. Therefore the selection of proxy, base period and downscaling technique should be carefully considered for future climate change impact studies concerning debris flow activity and associated fast-moving landslides.
\end{abstract}

\section{Introduction}

Debris flows are a common mass movement hazard in mountainous areas, with extreme rainfall the most common trigger for fatal debris flows (Dowling and Santi 2014), although snowmelt can also contribute in spring. For the Alps, the main trigger of debris flows is high intensity, short

Electronic supplementary material The online version of this article (doi:10.1007/s10584-016-1657-6) contains supplementary material, which is available to authorized users.

Thea Turkington t.a.r.turkington@utwente.nl

1 Faculty of Geo-Information Science and Earth Observation, University of Twente, Enschede, The Netherlands

2 Institut de Physique du Globe de Strasbourg, University of Strasbourg, Strasbourg, France 
duration rainfall (Schneuwly-Bollschweiler and Stoffel 2012; Stoffel et al. 2014; van den Heuvel et al. 2016). Under future climate change, it is likely that increases in extreme rainfall will alter debris flow frequency (Winter et al. 2010). A better understanding of how the frequency of debris flow days may change in the future is vital, especially for planning decisions in such mountainous environments, where often the settlements are located on alluvial fans.

Different meteorological proxies have been used for debris flow occurrence. Rainfall intensity-duration thresholds are often applied to determine minimum rainfall conditions under which debris flows may occur, and can be seen as a proxy for debris flow activity (Guzzetti et al. 2008; Nikolopoulos et al. 2014). However, while debris flows are often preceded by intense rainfall, capturing the rainfall in mountain catchments can be difficult due to the lack of rain gauges or poor coverage by weather radar in mountainous regions (Nikolopoulos et al. 2014; Pavlova et al. 2014). Therefore, other meteorological proxies for debris flow occurrence can account for deficiencies in precipitation records, either without (Turkington et al. 2014) or alongside rainfall (Paranunzio et al. 2015; Rulli et al. 2007). Temperature has been used where snow and thaw can contribute to debris flow occurrence (e.g. Paranunzio et al. (2015)) as well as to distinguish between snow and rain (e.g. van den Heuvel et al. (2016)). Previous work demonstrated that atmospheric variables, such as specific humidity (Q) combined with atmospheric instability through Convective Available Potential Energy (CAPE), can be used as proxies for debris flow occurrence, especially for those triggered by intense convective rainfall unrecorded by a rain gauge (Turkington et al. 2014).

For future projections, General Circulation Models (GCMs) are considered primary tools for climate impact studies (Kendon et al. 2010), for rainfall, humidity, as well as CAPE (Romps et al. 2014). Recent studies assessing the quality of GCMs have found that the models can replicate most of the changes in the historical climate (Brands et al. 2013; Sillmann et al. 2013). GCMs also replicate the observed increase in the annual-daily maximum rainfall, an important parameter for debris flows, although the GCMs underestimate the rainfall magnitude (Asadieh and Krakauer 2015). Furthermore, while GCMs provide the basis for future climate projections, model resolution is often at a much coarser scale than most debris flow source areas, restricting the use of GCM precipitation directly.

By downscaling the global projections using regional climate models (RCMs), changes in the relevant meteorological variables can be examined at a finer scale. This is especially important for mountainous regions where orographic processes are not always adequately captured in the global models. For the Alps, finer resolution climate models improved the spatial representation of precipitation compared to GCMs (Christensen et al. 2009), and simulate reasonably well mean and heavy precipitation (Rajczak et al. 2013). However, the projected changes in precipitation also depend on the driving GCM (Kjellström et al. 2011; Nikulin et al. 2011). Furthermore, RCMs at grid resolution 25-50 km are still coarser than cloud-resolving models, with biases remaining in precipitation (Rajczak et al. 2013). Therefore, the use of multiple RCMs in climate impact studies is advised.

Previously, a limited number of climate change impact studies focused on debris flows, with inconsistent results. Changes in heavy summer precipitation is expected to reduce the number of debris flows in the Massif des Ecrins, France (Jomelli et al. 2009). For the Swiss Alps, Stoffel et al. (2014) also found a decrease in intense summer precipitation, although the 
authors discuss the possibility of unprecedented debris flows due to changes in stability of rock glaciers. Melchiorre and Frattini (2012), using changes in extreme precipitation from a variety of climate models, found a wide spread of future results and concluded that accurate quantification of changes in the number of debris flows was not possible.

This paper assesses future projected changes in debris flow activity in two European Alpine areas, based on meteorological proxy, GCM, RCM, and Representative Concentration Pathways (RCPs) for the period 2010-2100. Although it is well established that numerous climate models and downscaling techniques are required for climate impact studies (Déqué et al. 2012; Dobler et al. 2013), this work examines their contributions for debris flows specifically. Furthermore, this study examines the role of meteorological proxy on future debris flows using not only precipitation, but also CAPE combined with humidity, to capture instability and moisture needed to sustain deep convection. An ensemble of 64 projections based on three RCMs, six driving GCMs, two RCPs, and two base periods (1950-1979 and 1980-2009), are used to compare future debris flow activity in the Barcelonnette Basin (France) and the Fella River catchment (Italy). An additional eight projections derived from CAPE and Q using four GCMs and two RCPs are also obtained. Ultimately, this work aims to determine the importance of choosing meteorological proxies in climate impact studies for debris flows.

\section{Data and methodology}

\subsection{Study areas}

To examine the role of meteorological proxies in assessing future debris flow activity, case study areas need to have both long continuous precipitation records and sufficiently complete debris flow inventories. The two European alpine areas considered in this work fulfill these criteria: the Barcelonnette Basin, France and the Fella River catchment, Italy (Fig. 1). Both have daily precipitation records covering 1950-2009, and were exposed to numerous documented debris flows (Barcelonnette: 99 over 66 days, Fella River: 335 over 24 days). The areas are known to have high intensity rainfall as primary trigger for debris flows, allowing for similar meteorological proxies to be used in both areas (Borga et al. 2007; Remaitre and Malet 2010). Sub-daily rainfall, although often a precursor for debris flows, was not considered due to the short available records and because daily rainfall totals are considered more reliably reproduced in climate models (Maraun et al. 2010).

In the Barcelonnette Basin, the climate-debris flow relationships have been analysed for the recent times at the annual, daily and hourly time scales (Remaitre and Malet 2010). Years with excess rainfall correspond to those with many debris flows, however, some relatively dry periods are also characterized by the occurrence of more than normal debris flows, testifying of the complexity of the climate-debris flow relationships. At daily scale, on the basis of 99 dated debris flows, two climate situations have been identified: one with heavy daily rainfall associated to violent summer thunderstorms following a 30-day dry period and the other with heavy cumulative rainfall distributed over a 30-day very humid period associated with prevailing westerly circulations.

The Fella River catchment regularly experiences debris flows and flash floods due to heavy precipitation from synoptic features as well as mesoscale convection (Borga et al. 2007). During winter, precipitation is derived primarily from synoptic features such as lows and fronts, varying significantly from year to year (Ceschia et al. 1991). In the summer months, convective processes become more important for rainfall generation, with local daily totals 

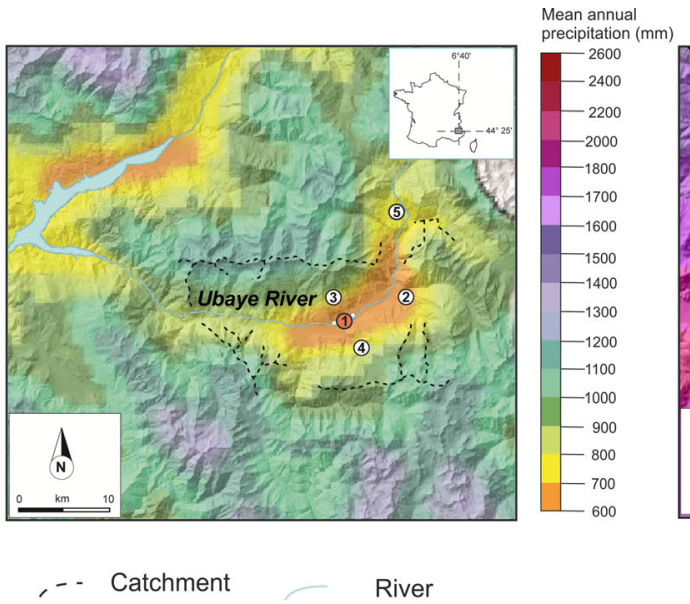

2600
-2400
-2200

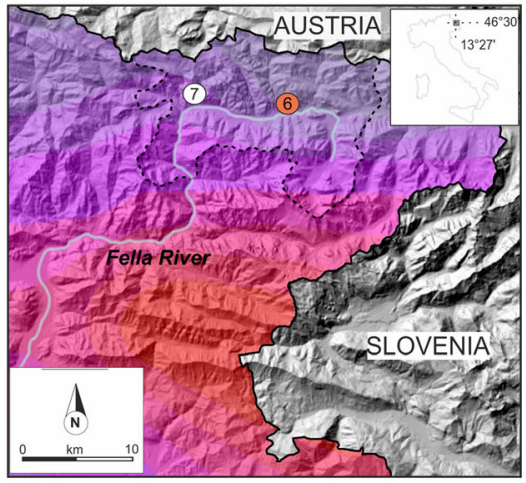

Rain Gauges:
(1) Barcelonnette $(1155 \mathrm{~m})$ (4) Sauze-La Rente $(1680 \mathrm{~m})$
(6) Malborghetto $(733 \mathrm{~m})$
(2) Jausiers (1510m)
(5) La Condamine $(1325 \mathrm{~m})$
(7) Pontebba (568 m)
(3) Les Clost $(1815 \mathrm{~m})$

Fig. 1 Geographical location and mean annual rainfall (1950-2009) for the study areas: Barcelonnette Basin (left) and Fella River catchment (right), with the rain gauges used in orange

exceeding $400 \mathrm{~mm}$ (Borga et al. 2007). The most recent catastrophic event was in August 2003, when more than $400 \mathrm{~mm}$ of rainfall was recorded, triggering more than 100 debris flows. More detailed information on the climate, debris flow occurrence, and geomorphological setting of both areas is in the supplementary material.

\subsection{Meteorological proxies for debris flows}

Two meteorological proxies for debris flow activity (days with at least 1 debris flow) were considered: one using observed 1-day precipitation amounts (rain-proxy) and a second based on modeled CAPE and specific humidity at $750 \mathrm{hPa}$ (QCAPEproxy). The rain-proxy was chosen as precipitation is a dominant trigger of debris flows. As rain gauges are very local and often non-catchment representative, the QCAPE-proxy was used to mimic the mesoscale atmospheric conditions leading to heavy local convective precipitation. Turkington et al. (2014) showed that a QCAPE-based proxy could outperform daily precipitation and multiple day precipitation amounts as a proxy for debris flows in the Barcelonnette Basin. QCAPEproxy was derived from ERA-Interim reanalysis dataset, for the period 1979-2011 (Dee et al. 2011). Mixed layer CAPE was calculated based on 18 levels from the reanalysis data of temperature, specific humidity, and geopotential height at 00, 06, 12 and 18 UTC as daily CAPE values were considered as insufficient to resolve deep convection (Romps et al. 2014).

For both daily proxies, a probabilistic approach (Berti et al. 2012) was applied to determine the relation between the meteorological event and debris flow activity. While many methods result in deterministic thresholds, a probabilistic approach has previously been proposed, due to other non-meteorological conditions triggering debris flows (Berti et al. 2012). From Bayes 
theorem, the conditional probability $(\mathrm{P}(\mathrm{A} \mid \mathrm{B}))$ that one or more debris flows (debris flow day, A) occur due to a particular meteorological event (B), such as heavy rainfall, can be derived as:

$$
P(A \mid B)=\frac{P(B \mid A) P(A)}{P(B)}
$$

where $\mathrm{P}(\mathrm{B} \mid \mathrm{A})$ is the conditional probability that a meteorological event $(\mathrm{B})$ will occur given a debris flow day $(\mathrm{C})$, and $\mathrm{P}(\mathrm{A})$ is the prior probability of a debris flow day and $\mathrm{P}(\mathrm{B})$ is the prior probability of the meteorological event.

For the rain-proxy, the probability of a debris flow day was computed for six rainfall bins. The rainfall bins were allowed to differ between study areas as non-climatic factors, such as land cover or geology, make local proxy-debris flow relationships catchment dependent (Guzzetti et al. 2008). The probabilities were determined for summer (JJAS) and yearly to separate rainfall-only events from ones possibly influenced by snow and snowmelt. Long records of precipitation and debris flows allowed the rain-proxy to be computed for two base periods, 1950-1979 and 1980-2009. For QCAPE six bins were created based on a combination of CAPE and Q values, with bins bounded by the lowest and highest CAPE and Q values observed on a debris flow day. Based on ERA-interim data availability, QCAPE-proxy was computed for the base period 1980-2009. To test if the probability of debris flow days for both proxies was greater than chance, a Monte Carlo simulation was undertaken. 10,000 dummy debris flow datasets were randomly generated using the same number of dates as observed debris flow days, and the probability of a debris flow day in each bin was calculated. Any probability used in the proxy that was greater than $95 \%$ of the runs for a particular bin was assumed to be significant.

\subsection{Future climate projections}

To assess the impact of future climate on debris flow frequency, the choice of climate model and RCP were considered as potential uncertainties along with the choice of proxy and base period. For the rain-proxy, three RCMs in combination with two RCP scenarios (RCP4.5 and RCP8.5) driven by up to six GCMs were used for building an ensemble of 32 climate scenarios for period 2010-2099 from the EURO-CORDEX project (Jacob et al. 2014). For the QCAPE-proxy, four GCMs with RCP4.5 and RCP8.5 scenarios made an ensemble of eight climate scenarios (Taylor et al. 2011) as RCM data did not have sufficient information to assess CAPE accurately. Where possible, GCM models were selected based on their varying ability in representing climate extremes in the historical record (Sillmann et al. 2013), as well as differences in model genealogy (Knutti et al. 2013). Further information about the models used is in the supplementary material (S2). The debris flow day frequency based on GCM and RCM datasets was calculated based on the yearly probability computations as described in Section 2.2.

For realistic climate change scenarios, both RCM and GCM data have to be corrected for biases (Gudmundsson et al. 2012). Quantile-mapping was applied based on Themeß1 et al. (2012). Empirical cumulative distribution functions (CDFs) of climate models were mapped to the CDFs from the observed data for each month of the year over 1950 to 2009 for the rainproxy and 1980-2009 for the QCAPE-proxy. Bias-correction was applied to the RCM data for the rain-proxy. For the QCAPE-proxy, the calculated CAPE values were corrected for biases, rather than the individual temperature and humidity profiles. Two sizes of the area for quantile mapping are assessed for its impact on future debris- low days: $0.5^{\circ} \times 0.5^{\circ}$ and $2.0^{\circ} \times 2.0^{\circ}$. Further information can be found in the supplementary material (S3). 


\section{Results}

Bias-corrected climate change projections for two meteorological proxies, rain-proxy and QCAPE-proxy (Section 3.1), were used as basis for future projections of frequency of debris flow days (Section 3.2).

\subsection{Meteorological proxies for debris flows}

Using the rain-proxy, the probability of debris flow days generally increased with higher daily rainfall totals for both base periods and in both regions (Fig. 2 and Table S4). The probability of a debris flow days was significant for all rain-proxy bins except for the lowest rainfall bin and the second lowest rainfall bin for the Fella River catchment (Table S8). In the Barcelonnette Basin the highest yearly probability (43.5\%) was associated with the second highest rainfall bin (40-50 mm) for the base period 1980-2009 and not with the highest observed rainfall. The probability of a debris flow day for each of the rainfall bins in summer was also always equal or higher than the probability over all seasons. The higher absolute number of debris flow days (Table S5) observed in the later base period explains the higher probability associated with certain rain-proxies in Fig. 2. For the Fella River catchment, the second base period had 17 more debris flow days than the first base period. The increase in debris flow days was partly due to changes in precipitation, as using the first base period rainproxy, 0.4 more debris flow days would be expected in 1980-2009, or an increase of 2.1 days using the second base period rain-proxy. Between 1950 and 1979 the Fella River catchment did not record rainfall over $150 \mathrm{~mm}$, while two large rainfall events in 1996 (192 mm) and $2003(354 \mathrm{~mm}$ ) triggered more than 200 debris flows, explaining non-values in the last bin for the first base period and over $66.7 \%$ probability for the second base period. For the Barcelonnette Basin, the first base period rain-proxy predicts a decrease of 2.5 debris flow days between 1950 and 1979 and 1980-2009, and 7 days for the second period rain-proxy. The predicted decrease in debris flow days between 1950 and 1979 and 1980-2009 contrasts the observed increase of 32 debris flow days during the same period.

For the QCAPE-proxy, CAPE values over $4400 \mathrm{~J} / \mathrm{kg}$ in combination with high humidity values $(>7.0 \mathrm{~g} / \mathrm{kg})$ had the highest probability for debris flow days in the Barcelonnette Basin, while the values for the Fella River catchment were over $4200 \mathrm{~J} / \mathrm{kg}$ and $5.0 \mathrm{~g} / \mathrm{kg}$ (Fig. 2 and Table S6). The probability of a debris flow days was significant for all QCAPE proxy bins for Barcelonnette, although only for the two highest and second lowest bin for the Fella River catchment (Table S8). The summer debris flows were all associated with high humidity, while spring and autumn debris flows occurred under lower humidity conditions. The QCAPE-proxy did not perform as well for the Fella River catchment as for the Barcelonnette Basin, due to the lower probability of debris flow days for highest QCAPE bins.

\subsection{Future debris flow frequency}

\subsubsection{Rain-proxy based debris flow projections}

Using the rain-proxy, the number of debris flow days increased in most future projections compared to the period 1950-1979 for both the Barcelonnette Basin and the Fella River catchment during the 20th and 21st century (Fig. 3a). For the Barcelonnette Basin, the mean relative trend of debris flow days from all projections is $2.4 \%$ per decade $\left(\% \mathrm{~d}^{-1}\right)$ for the period 
a

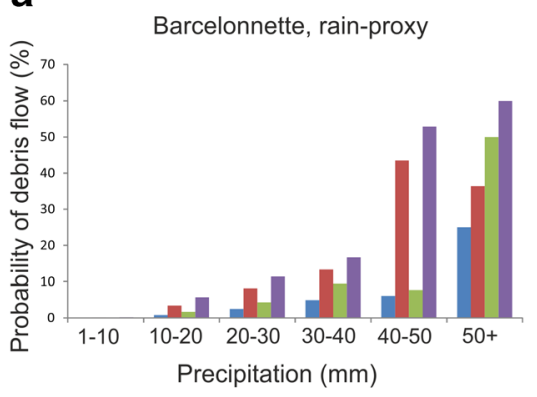

All seasons 1950-1979

C

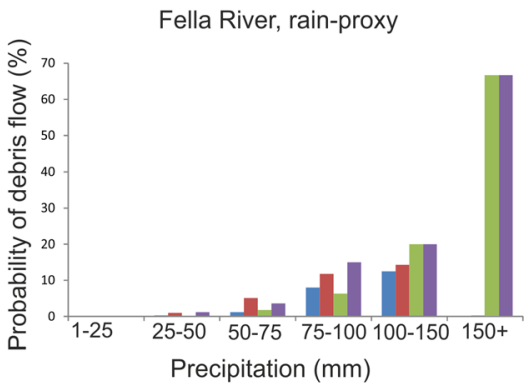

b

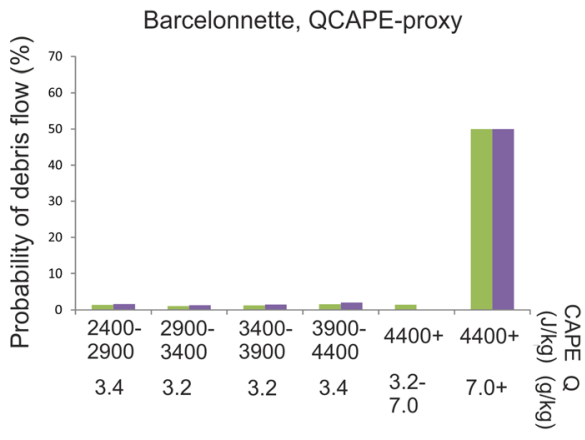

All seasons 1980-2009

Summer 1980-2009

d

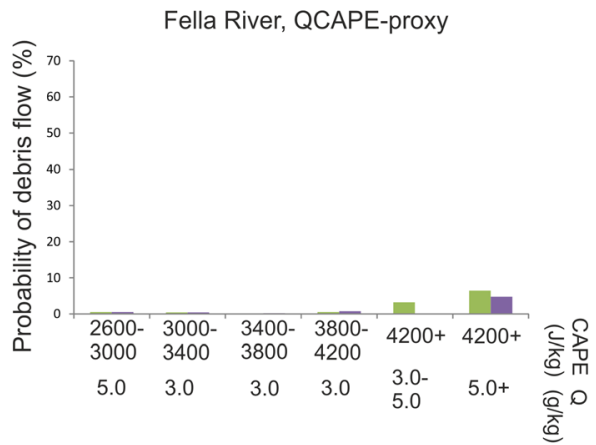

Fig. 2 Probability of a debris flow day for the rain-proxy (left) and QCAPE-proxy (right)

1950-2099. Most projections (48 out of 64) showed a small positive trend $\left(1-5 \% \mathrm{~d}^{-1}\right)$, whereas 5 projections showed a larger positive trend $\left(5-6.2 \% \mathrm{~d}^{-1}\right)$ and 11 have no trend (less than $\left.1 \% \mathrm{~d}^{-1}\right)$. For Fella the future projections had an even larger increase of $4.6 \% \mathrm{~d}^{-1}$ for $1951-$ 2099. Here, 28 out of 64 projections increased between 5.0 and $11.4 \% \mathrm{~d}^{-1}$, while 32 projections showed an increase in the number of debris flow days between 1 and $5 \% \mathrm{~d}^{-1}$ and 4 had no trend (less than $1 \% \mathrm{~d}^{-1}$ ). The number of days in each rain-proxy bin for the final period (2070 2099) can be found in the supplementary material (Table S5).

For the Barcelonnette Basin, the relative future trend in debris flow days was most sensitive to the base period and the driving GCM or RCM, rather than the area for quantile mapping or RCP (Fig. 3, S1). The base period used (1950-1979 or 1980-2009) for the rain-proxy significantly affected the relative increase in the number of debris flow days (Fig. 3c). The first base period had a greater trend $\left(3.0 \% \mathrm{~d}^{-1}\right)$ compared to the second base period $\left(1.7 \% \mathrm{~d}^{-1}\right)$. However, based on Table S5, the absolute number of debris flow days would be smaller in the future using the earlier base period (21.6 debris flow days for 2070-2099, compared with 56.5 debris flow days for 2070-2099 using the second base period). Of less importance was whether a larger area of $2^{\circ} \times 2^{\circ}$, similar to GCM grid-size, or a reduced area of $0.5^{\circ} \times 0.5^{\circ}$ was used for quantile mapping. The larger area led to an increase in debris flow days of $2.8 \% \mathrm{~d}^{-1}$, compared to $2.0^{\circ} \% \mathrm{~d}^{-1}$ for the reduced area (Fig. 3b). Based on the two-sample Kolmogorov-Smirnov test (Massey 1951), the two groups were not significantly different at the $5 \%$ significance level. When comparing RCPs, the average trend was $2.4 \% \mathrm{~d}^{-1}$ for both 
a

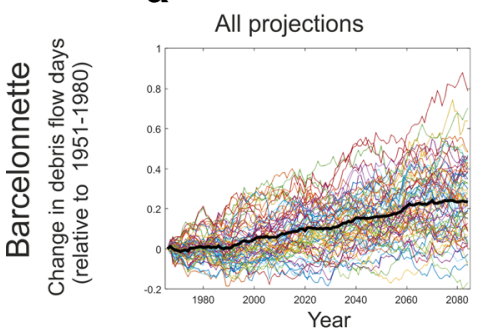

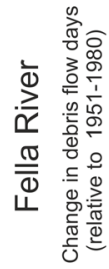

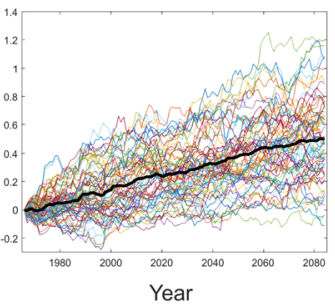

a
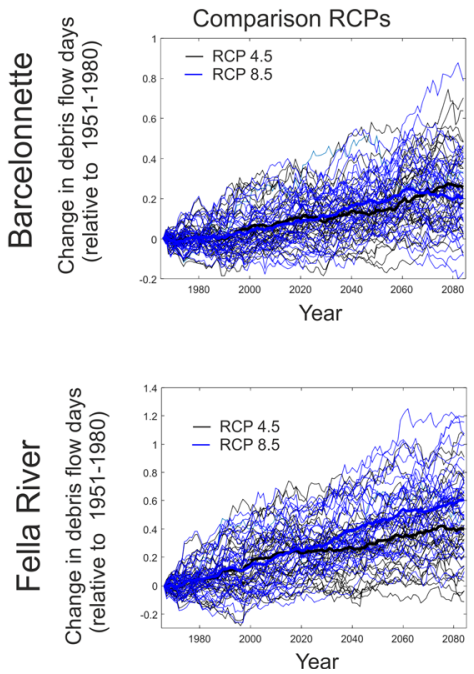

b
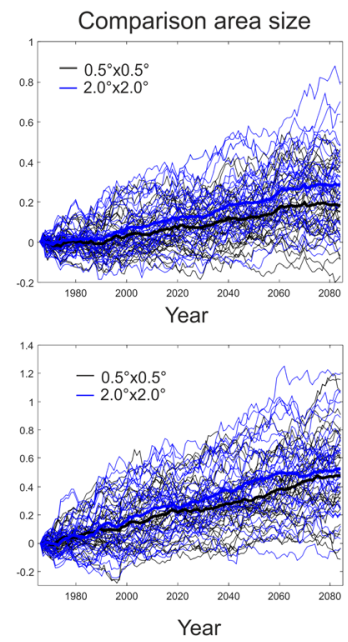

b
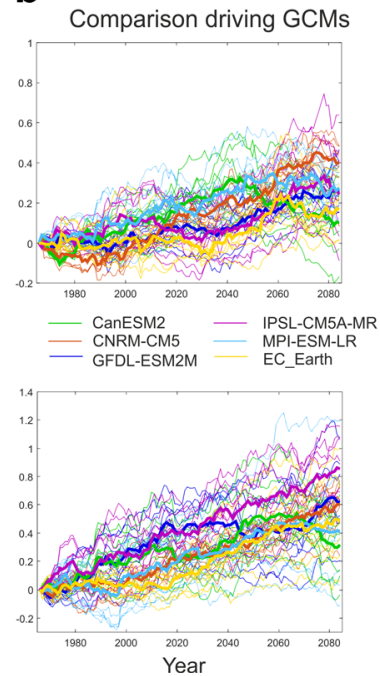

C
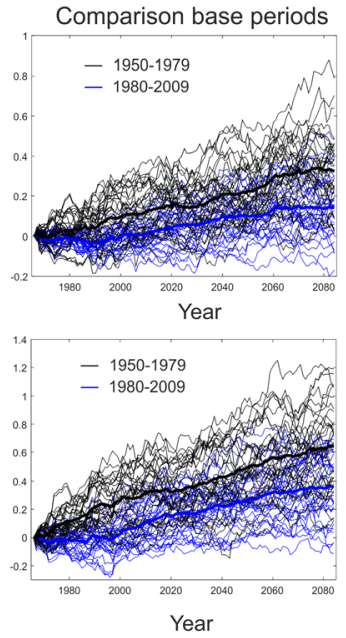

C
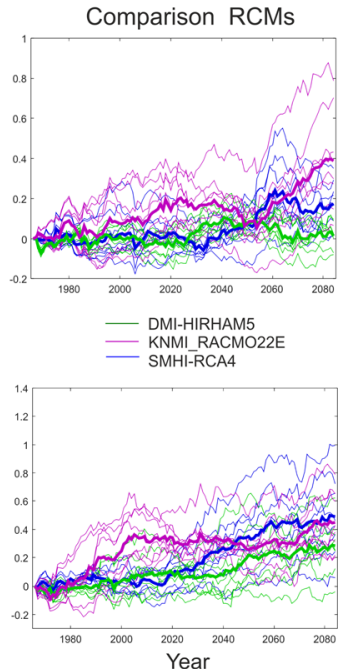

Fig. 3 Change in number of debris flow days using rain-proxy, for all projections (2a, with mean projection in black), and $\mathbf{b}, \mathbf{c}, \mathbf{d}$, and e plot projections for comparison, with d, only using RCM SMHI-RCA4 and for e, only the EC-EARTH GCM was used (bold line indicates mean projection)

RCPs (Fig. 3d). The trend for the RCP depended on the driving GCMs; the driving GCM MPI-ESM-LR had a larger positive trend under RCP8.5, where EC-EARTH had a less pronounced trend under RCP8.5. Looking at projections using RCM SHMI-RCA4 driven by different GCMs (Fig. 3e), the mean increase in number of debris flow days was highest using CNRM-CM5 (orange, $4.9 \% \mathrm{~d}^{-1}$ ), and was significantly higher than the other five groups $\left(1.7-2.9 \% \mathrm{~d}^{-1}\right)$. The projections by three RCMs driven by EC-EARTH differed by the end of 21st century, with the DMI-HIRHAM5 RCM showing a significantly smaller increase than with the other two RCMs (Fig. 3f).

For the Fella River catchment, the range in projected relative number of debris flow days based on the rain-proxy was considerable larger than the Barcelonnette Basin by 2100 (Fig. 3). 
Additionally, the factors impacting the future trend were different. For the Fella River catchment, the relative trend was most sensitive to the base period and the RCP scenario, and not to the choice of RCM or GCM. The different base periods resulted in a significantly different average trend of $5.2 \% \mathrm{~d}^{-1}$ for $1950-1979$ and $3.9 \% \mathrm{~d}^{-1}$ for $1980-2009$ (Fig. 3c). The stronger trend using 1950-1979 was partly due to the lower absolute number of debris flow days in this period (Table S5). The difference between base periods is largest using GCM ECEARTH model, with a more than doubling of the trend depending on the base period for both RCPs. This was in line with the general trend, where the average increase in number debris flow days was significantly greater under RCP8.5 $\left(5.6 \% \mathrm{~d}^{-1}\right)$ than RCP4.5 $\left(3.5 \% \mathrm{~d}^{-1}\right)$ as seen in Fig. $3 \mathrm{~d}$. The area for quantile mapping did not result in two significant different groups; trends of $5.0 \% \mathrm{~d}^{-1}$ for $2^{\circ} \times 2^{\circ}$ area and $4.1 \% \mathrm{~d}^{-1}$ for $0.5^{\circ} \times 0.5^{\circ}$ area, respectively (Fig. 3b). For the GCMs driving RCM SHMI-RCA4, the trend varied between $4.0 \% \mathrm{~d}^{-1}$ (CanESM2) and $6.8 \% \mathrm{~d}^{-1}$ (IPSL-CM5A-MR) (Fig. 3e). Similarly, the RCM choice was of less importance to the relative trend, with no significant differences between the three RCM models (Fig. 3f).

\subsubsection{QCAPE-proxy based debris flow projections}

For both study areas, the QCAPE-proxy showed a statistically significant smaller increase in future debris flow days than the rain-proxy projections, $0.3 \% \mathrm{~d}^{-1}$ against $3.6 \% \mathrm{~d}^{-1}$ for the rainproxy for Barcelonnette (Fig. 4a) and $1.2 \% \mathrm{~d}^{-1}$ for Fella River compared with $4.1 \% \mathrm{~d}^{-1}$ using the rain-proxy (Fig. 4b). However, mean QCAPE-proxy projections were based on fewer scenarios than the rain-proxy ( 8 versus 32) due to absence of two base periods and lack of RCM projections. Therefore, Figs. 4c, d, e, and f compare directly projections from the same GCM using QCAPEproxy and rain-proxy for both RCP scenarios. The number of days in each QCAPE bin for the final period (2070-2099) can be found in the supplementary material (Table S7).

For the Barcelonnette Basin, generally most QCAPE-proxy projections showed similar changes in debris flow days compared to rain-proxy, but of smaller magnitude. For CanESM2, the QCAPE and rain-proxies were most in line with each other: all projections are in the range of $1.8-4.4 \% \mathrm{~d}^{-1}$. CNRM-CM5 projections both had the largest increase in debris flow days for both proxies. Using GFDL-ESM2M, the QCAPE-proxy resulted in a decrease to no change whereas the rain-proxy resulted in an increase in debris flow activity. QCAPE-proxy for IPSL_C5A-MR RCP8.5 had the largest overall decrease in debris flow days of $1.4 \% \mathrm{~d}^{-1}$.

For the Fella River catchment, generally the QCAPE-proxy projections showed a similar change as the rain-based proxy, although the CanESM2 QCAPE-proxy increased more than the rain-proxy, while for all other GCMs, the rain-proxy had a larger increase. Using GFDL-ESM2M, the QCAPE-proxy projections showed an earlier onset of decrease in debris flow days, resulting in an average decrease of $1.1-2.7 \% \mathrm{~d}^{-1}$. The largest increase in debris flow days was based on the CanESM2 GCM, with an increase of 4.0 and $5.2 \% \mathrm{~d}^{-1}$ for RCP 4.5 and 8.5 respectively.

\section{Discussion and conclusion}

Using the rain-proxy results in a higher future debris flow activity compared to the QCAPE-proxy. Both proxies show an increase in the probability of debris flow days with increasing values: a general increase using observed daily precipitation, where the QCAPE-proxy provides a clear threshold above which debris flows are more likely. The differences may be due to the proxies being associated with different atmospheric conditions. The QCAPE-proxy is representative of 
a

All QCAPE-proxy projections, Barcelonnette

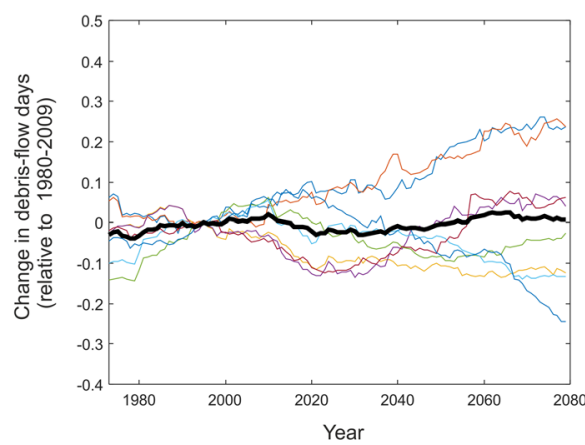

d
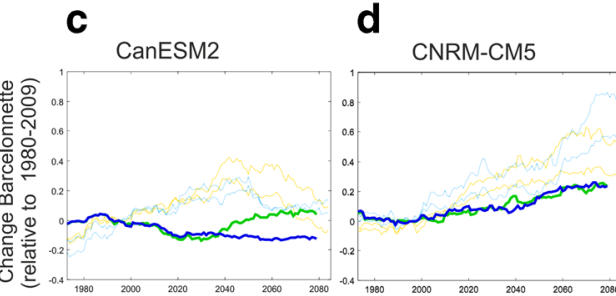

b

All QCAPE-proxy projections, Fella River

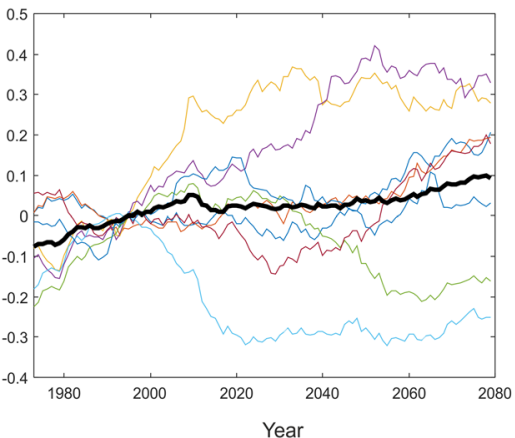

e

f

GFDL-ESM2M

IPSL_CM5A-MR
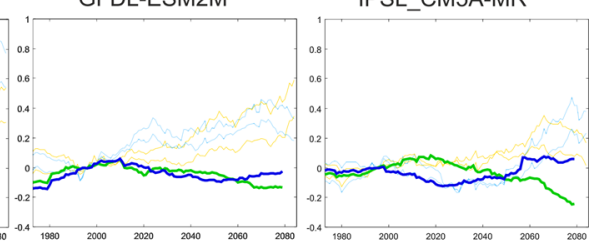

- QCAPE $8.5-$ RR $8.5-$ QCAPE $4.5-$ RR 4.5
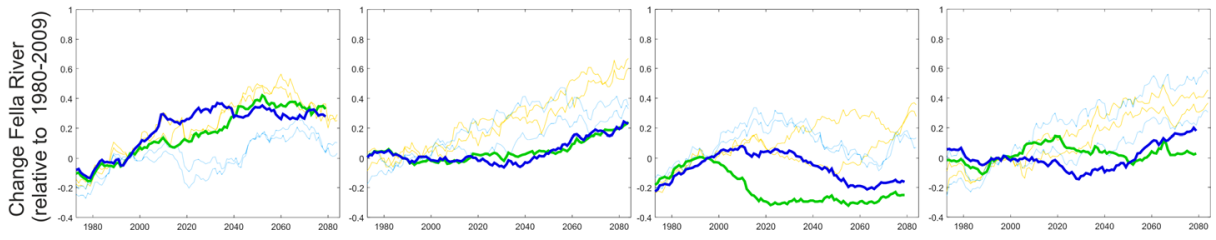

Fig. 4 Change in debris flow days using QCAPE-proxy $\mathbf{a}$ and $\mathbf{b}$ with the mean change in debris flow days is in black, $\mathbf{c}-\mathrm{f}$ compare each of the QCAPE-proxy projections with the rain-proxy projections from the same GCM, where the projection using RCP 4.5 is in green (QCAPE-proxy) and yellow (rain-proxy), and using RCP 8.5 in dark blue (QCAPE-proxy) and light blue (rain-proxy)

short-lasting convective rainfall systems existing in a mesoscale humid environment triggering debris flows (Turkington et al. 2014). The rain-proxy includes all synoptic conditions producing sufficient rainfall to trigger a debris flow as it is based on observational records. These conditions range from stable low pressure systems causing multiple days of rain to short duration convection cells. For the Barcelonnette Basin, high QCAPE values have as high a probability as the highest rain-proxy values, which suggests that QCAPE-proxy might serve here as an alternative for rainbased projections. The QCAPE associated probability is lower for the Fella River catchment (6\%) compared to the Barcelonnette Basin (50\%) and to the rain-proxy (67\%). Likely, in the Fella River catchment, atmospheric instability and specific humidity at $750 \mathrm{hPa}$ are not able to separate well the convective events than may or may not trigger debris flows.

In both areas, the increase in the number of future debris-flow days is greater using the more recent base period, under the assumption that the relationship between debris flows and proxies is constant. However, the relationship has apparently changed from 1950 to 1979 to 1980-2009, as the number of debris-flow days increased more than predicted by the same rainproxies in both study areas. Reasons for lower probabilities for the base period 1950-1979 
versus 1980-2009 include underreporting of events in the earlier period, or non-climatic changes, along with past climate change. Historically, European landslide inventories are thought to become stable from 1970 onwards (Wood et al. 2015), and observed changes in debris flows may have been dominated by human mitigation factors (Crozier 2010). Another factor that may alter the proxy-debris flow relationship are changes in sub-daily precipitation intensity, as the same amount of precipitation over a shorter period of time is more likely to trigger a debris flow (e.g. Guzzetti et al. (2008)). As a non-climatic actor, changes in sediment availability might impact the relationship between a proxy and debris flows as changes in permafrost resulted in unprecedented debris flows (Stoffel et al. 2014). Additional factors, such as the role of snowmelt and future mitigation works, are not taken into account in this work.

The area for quantile mapping had a smaller effect on debris flow frequency than base period. Generally the internal variability in the climate has a larger contribution to the climate signal on smaller scales (Hawkins and Sutton 2011), and may be the reason why the $2^{\circ} \times 2^{\circ}$ area for quantile mapping shows a slightly larger increases in debris flow days for both study areas. Although a larger area may not be as representative of local changes, such as in the Barcelonnette Basin, which is drier than the surrounding area (Fig. 1).

The results demonstrate that a probabilistic approach in combination with quantile mapping is capable of translating climate change scenarios in future debris flow activity. The projections displayed a wide range of results for future debris flow frequency, similar to the findings of Melchiorre and Frattini (2012). Projected changes in the number of debris flow days however cannot be used directly in hazard and risk assessments, as they require a relation between the frequency of occurrence and the spatial distribution of debris flow intensities. To convert the results into useful hazard data would require more detailed information about the change in magnitude of debris flow events, which was not considered and is an avenue for future work in both study areas.

In this study, future climate projections are translated into future debris flow activity for two Alpine catchments. All projections show either an increase or little change in the number of days with debris flows, where the increase is greater for the Fella River catchment (QCAPEproxy: $1.2 \% \mathrm{~d}^{-1}$, rain-proxy: $4.6 \% \mathrm{~d}^{-1}$ ), compared to the Barcelonnette Basin (QCAPE-proxy: $0.3 \% \mathrm{~d}^{-1}$, rain-proxy: $2.4 \% \mathrm{~d}^{-1}$ ). The projections depend strongly on the base period and proxy used, and to a lesser extent GCM, RCM, RCP scenario, and area for quantile mapping. Therefore the base period and proxy used should be carefully considered when developing future projections of debris flow activity.

Acknowledgments This work was undertaken as part of the EU FP7 Marie Curie ITN project CHANGES. Data used in this study were provided by Météo France, and the Hydraulic Service, FVG, Italy. We also acknowledge the World Climate Research Programme's Working Group on Regional Climate, and the Working Group on Coupled Modelling, former coordinating body of CORDEX and responsible panel for CMIP5. We also thank the climate modelling groups for producing and making their model output available.

Open Access This article is distributed under the terms of the Creative Commons Attribution 4.0 International License (http://creativecommons.org/licenses/by/4.0/), which permits unrestricted use, distribution, and reproduction in any medium, provided you give appropriate credit to the original author(s) and the source, provide a link to the Creative Commons license, and indicate if changes were made.

\section{References}

Asadieh B, Krakauer NY (2015) Global trends in extreme precipitation: climate models versus observations. Hydrology and Earth System Science 19:877-891. doi:10.5194/hess-19-877-2015 
Berti M, Martina MLV, Franceschini S, Pignone S, Simoni A, Pizziolo M (2012) Probabilistic rainfall thresholds for landslide occurrence using a Bayesian approach. J Geophys Res-Earth Surf 117. doi:10.1029/ 2012jf002367

Borga M, Boscolo P, Zanon F, Sangati M (2007) Hydrometeorological analysis of the 29 august 2003 flash flood in the Eastern Italian Alps. J Hydrometeorology 8:1049-1067. doi:10.1175/jhm593.1

Brands S, Herrera S, Fernández J, Gutiérrez JM (2013) How well do CMIP5 earth system models simulate present climate conditions in Europe and Africa? Clim Dynam 41:803-817. doi:10.1007/s00382-013-1742-8

Ceschia M, Micheletti S, Carniel R (1991) Rainfall over Friuli-Venezia Giulia: high amounts and strong geographical gradients. Theor Appl Climatol 43:175-180. doi:10.1007/bf00867452

Christensen JH, Rummukainen M, Lenderink G (2009) Formulation of very-high-resolution regional climate models. In: van der Linden P, Mitchell JFB (eds) ENSEMBLES: climate change and its impacts: summary of research and results from the ENSEMBLES project. Met Office, Hadley Centre, Exeter, United Kingdom, pp. $47-58$

Crozier MJ (2010) Deciphering the effect of climate change on landslide activity: A review. Geomorphology 124:260-267. doi:10.1016/j.geomorph.2010.04.009

Dee DP, Uppala SM, Simmons AJ, Berrisford P, Poli P, Kobayashi S, Andrae U, Balmaseda MA, Balsamo G, Bauer P, et al. (2011) The ERA-interim reanalysis: configuration and performance of the data assimilation system. Q J Roy Meteor Soc 137:553-597. doi:10.1002/qj.828

Déqué M, Somot S, Sanchez-Gomez E, Goodess C, Jacob D, Lenderink G, Christensen O (2012) The spread amongst ENSEMBLES regional scenarios: regional climate models, driving general circulation models and interannual variability. Clim Dyn 38:951-964. doi:10.1007/s00382-011-1053-x

Dobler C, Bürger G, Stötter J (2013) Simulating future precipitation extremes in a complex alpine catchment. Nat Hazard Earth Sys 13:263-277. doi:10.5194/nhess-13-263-2013

Dowling C, Santi P (2014) Debris flows and their toll on human life: a global analysis of debris-flow fatalities from 1950 to 2011. Nat Hazards 71:203-227. doi:10.1007/s11069-013-0907-4

Gudmundsson L, Bremnes JB, Haugen JE, Engen-Skaugen T (2012) Technical note: downscaling RCM precipitation to the station scale using statistical transformations \&ndash; a comparison of methods. Hydrol Earth Syst Sci 16:3383-3390. doi:10.5194/hess-16-3383-2012

Guzzetti F, Peruccacci S, Rossi M, Stark C (2008) The rainfall intensity-duration control of shallow landslides and debris flows: an update. Landslides 5:3-17. doi:10.1007/s10346-007-0112-1

Hawkins E, Sutton R (2011) The potential to narrow uncertainty in projections of regional precipitation change. Clim Dynam 37:407-418. doi:10.1007/s00382-010-0810-6

Jacob D, Petersen J, Eggert B, Alias A, Christensen O, Bouwer L, Braun A, Colette A, Déqué M, Georgievski G, et al. (2014) EURO-CORDEX: new high-resolution climate change projections for European impact research. Reg Environ Chang 14:563-578. doi:10.1007/s10113-013-0499-2

Jomelli V, Brunstein D, Déqué M, Vrac M, Grancher D (2009) Impacts of future climatic change (2070-2099) on the potential occurrence of debris flows: a case study in the massif des ecrins (French Alps). Clim Chang 97: 171-191. doi:10.1007/s10584-009-9616-0

Kendon EJ, Jones RG, Kjellström E, Murphy JM (2010) Using and Designing GCM-RCM Ensemble regional climate projections. J Clim 23:6485-6503. doi:10.1175/2010JCLI3502.1

Kjellström E, Nikulin G, Hansson ULF, Strandberg G, Ullerstig A (2011) 21st century changes in the European climate: uncertainties derived from an ensemble of regional climate model simulations. Tellus A 63:24 40. doi:10.1111/j.1600-0870.2010.00475.x

Knutti R, Masson D, Gettelman A (2013) Climate model genealogy: generation CMIP5 and how we got there. Geophys Res Lett 40:1194-1199. doi:10.1002/grl.50256

Maraun D, Wetterhall F, Ireson AM, Chandler RE, Kendon EJ, Widmann M, Brienen S, Rust HW, Sauter T, Themeß1 M, et al. (2010) Precipitation downscaling under climate change: recent developments to bridge the gap between dynamical models and the end user. Rev Geophys 48:RG3003. doi:10.1029/2009rg000314

Massey FJ Jr (1951) The Kolmogorov-Smirnov test for goodness of fit. J Am Stat Assoc 46:68-78. doi:10.2307/ 2280095

Melchiorre C, Frattini P (2012) Modelling probability of rainfall-induced shallow landslides in a changing climate, otta, Central Norway. Clim Chang 113:413-436. doi:10.1007/s10584-011-0325-0

Nikolopoulos EI, Crema S, Marchi L, Marra F, Guzzetti F, Borga M (2014) Impact of uncertainty in rainfall estimation on the identification of rainfall thresholds for debris flow occurrence. Geomorphology 221:286297. doi:10.1016/j.geomorph.2014.06.015

Nikulin G, KjellstrÖM E, Hansson ULF, Strandberg G, Ullerstig A (2011) Evaluation and future projections of temperature, precipitation and wind extremes over Europe in an ensemble of regional climate simulations. Tellus A 63:41-55. doi:10.1111/j.1600-0870.2010.00466.x

Paranunzio R, Laio F, Nigrelli G, Chiarle M (2015) A method to reveal climatic variables triggering slope failures at high elevation. Nat Hazards 76:1039-1061. doi:10.1007/s11069-014-1532-6 
Pavlova I, Jomelli V, Brunstein D, Grancher D, Martin E, Déqué M (2014) Debris flow activity related to recent climate conditions in the French Alps: A regional investigation. Geomorphology 219:248-259. doi:10.1016/ j.geomorph.2014.04.025

Rajczak J, Pall P, Schär C (2013) Projections of extreme precipitation events in regional climate simulations for Europe and the alpine region. J Geophys Res-Atmos 118:3610-3626. doi:10.1002/jgrd.50297

Remaitre A, Malet J (2010) The effectiveness of torrent check dams to control channel instability: example of debris-flow events in clay shales. In: Garcia C, Lenzi M (eds) Check dams, morphological adjustments and erosion control in torrential streams, chapter 10. Nova Science Publishers, New York, pp. 211-237

Romps DM, Seeley JT, Vollaro D, Molinari J (2014) Projected increase in lightning strikes in the United States due to global warming. Science 346:851-854. doi:10.1126/science.1259100

Rulli MC, Meneguzzo F, Rosso R (2007) Wind control of storm-triggered shallow landslides. Geophys Res Lett 34:L03402. doi:10.1029/2006g1028613

Schneuwly-Bollschweiler M, Stoffel M (2012) Hydrometeorological triggers of periglacial debris flows in the Zermatt valley (Switzerland) since 1864. J Geophys Res-Earth Surf 117:F02033. doi:10.1029/ 2011JF002262

Sillmann J, Kharin VV, Zhang X, Zwiers FW, Bronaugh D (2013) Climate extremes indices in the CMIP5 multimodel ensemble: part 1. Model Evaluation in the Present Climate Journal of Geophysical ResearchAtmospheres 118:1716-1733. doi:10.1002/jgrd.50203

Stoffel M, Tiranti D, Huggel C (2014) Climate change impacts on mass movements - case studies from the European Alps. Sci Total Environ 493:1255-1266. doi:10.1016/j.scitotenv.2014.02.102

Taylor KE, Stouffer RJ, Meehl GA (2011) An overview of CMIP5 and the Experiment Design. Bull Am Meteorol Soc 93:485-498. doi:10.1175/BAMS-D-11-00094.1

Themeß1 M, Gobiet A, Heinrich G (2012) Empirical-statistical downscaling and error correction of regional climate models and its impact on the climate change signal. Clim Chang 112:449-468. doi:10.1007/s10584011-0224-4

Turkington T, Ettema J, van Westen CJ, Breinl K (2014) Empirical atmospheric thresholds for debris flows and flash floods in the Southern French Alps. Nat Hazards Earth Syst Sci 14:1517-1530. doi:10.5194/nhess-141517-2014

van den Heuvel F, Goyette S, Rahman K, Stoffel M (2016) Circulation patterns related to debris-flow triggering in the Zermatt valley in current and future climates. Geomorphology, Advanced Online Publication. doi:10. 1016/j.geomorph.2015.12.010

Winter MG, Dent J, Macgregor F, Dempsey P, Motion A, Shackman L (2010) Debris flow, rainfall and climate change in Scotland. Q J Eng Geol Hydroge 43:429-446. doi:10.1144/1470-9236/08-108

Wood JL, Harrison S, Reinhardt L (2015) Landslide inventories for climate impacts research in the European Alps. Geomorphology 228:398-408. doi:10.1016/j.geomorph.2014.09.005 